\title{
Parent support contribution and peer conformity on learning motivation
}

\author{
Anggi Fadilah ${ }^{\left.1^{*}\right)}$, Marjohan Marjohan ${ }^{2}$ \\ ${ }^{1}$ Universitas Negeri Padang
}

\begin{tabular}{l} 
Article Info \\
\hline Article history: \\
Received Jun $04^{\text {th }}, 2021$ \\
Revised Jul $19^{\text {th }}, 2021$ \\
Accepted Aug $19^{\text {th }}, 2021$
\end{tabular}

\section{Keyword:}

Parent support

Peer conformity

Learning

Motivation

\begin{abstract}
One that affects the success of student learning is motivation. Less motivation to learn in students will affect the decrease in enthusiasm for learning and learning outcomes. There are several factors that influence the motivation of students in learning, including the support of parents and peers. This research aims to; (1) Describe the contribution of parental support, peer conformity and students' learning motivation, and (2) examine the contribution of parental support and peer conformity together on students' learning motivation. This study uses a quantitative approach with analytical descriptive method. The sample in this study were students of class VII and VIII, a total of 108 students. This research instrument uses a Likert scale model. The data were analyzed by descriptive statistical techniques, then using simple linear regression analysis and multiple linear regression analysis. The research findings show that in general; 1) students' parental support is in the high category, peer conformity of students is in the very high category, students' learning motivation is in the very high category, and 2) there is a strong and positive relationship between parental support and students' learning motivation. . This research has implications for the educational process in schools as a contribution to parental support and positive peer conformity which makes students have high learning motivation and are confident in their own abilities.
\end{abstract}

(C) 2021 The Authors. Published by IICET.

This is an open access article under the CC BY-NC-SA license

(https://creativecommons.org/licenses/by-nc-sa/4.0)

\section{Corresponding Author:}

Anggi Fadilah

Universitas Negeri Padang

Email: fadilahanggi@gmail.com

\section{Introduction}

One of the factors that influence the success of student learning is motivation. Motivation will encourage students to be more active in learning and obtain high learning outcomes, while for students who do not have learning motivation will give low learning outcomes (Prawira \& Atmaja, 2012).

There are several indicators that support learning motivation, including: the desire and desire to succeed, the drive and need for learning, future hopes and aspirations, appreciation in learning, and a conducive learning environment (Uno \& Mohamad, 2011). The motivation of each individual is caused by a hierarchy of needs (needs). With the need, someone will try hard to achieve the desired goal because he feels the need for it, as well as the needs of each individual in learning, someone will try to carry out learning activities to achieve learning goals that must be passed through the appropriate process stages. In addition, students feel the need to learn to get new information or knowledge (Iskandar , 2009). 
Parental support is very much needed in children's learning so that they are able to get good learning achievements and in accordance with their expectations, so that their goals can be realized. With parental support, children will feel appreciated and cared for by their parents so that it will increase children's motivation to learn and will achieve an optimal learning achievement (Malwa, 2018).

The second factor that affects children is the peer environment. At the age of adolescence, students will look for peers who have in common with certain interests. The social influence that occurs in peers is based on the compatibility of perceptions between individuals. Groups that have an attachment will form a group climate and certain norms as the provision of behavioral norms by a group of friends. Teenagers in their association will form a group (Setiyo, 2017).

Study Yulia (2019) The results obtained that this study has a relationship between parental support variables and learning motivation in students of SMP Negeri 9 Filial Loa Kulu. The relevance of the above research with the researcher is that they both examine the variables of parental support and learning motivation, but previous studies did not examine the peer conformity variable.

Study Laila \& Ilyas (2019) The results show that there is a correlation between peer conformity and students' learning motivation with a fairly strong level of relationship strength, where the higher peer conformity, the lower the students' learning motivation. The relevance of the above research with the researcher is that they both examine the variables of peers and learning motivation, but previous studies did not examine the variables of parental support.

Research conducted by Herdiyanto \& Yuliantari (2015) The results show that there is a relationship between conformity and self-esteem with consumptive behavior in adolescent girls in Denpasar City. The results of the simultaneous significance test from the regression analysis carried out showed a significance of $0.000(p<0.05)$. Consumptive behavior and conformity, one of the factors that play a role in the formation of consumptive behavior is conformity. The more conformity of a teenager in the group, the more easily influenced to behave consumptively. Based on the significant correlation between self-esteem and consumptive behavior, it can be stated that one of the factors that play a role in the formation of consumptive behavior other than conformity is self-esteem.

Problems related to violations of school discipline were also carried out by students of SMP Pertiwi 2 Padang, including: students arriving late to school, not attending school without information, skipping school, getting involved in brawls or fights between students, and other violations of the rules that apply at school. , often students who skip school and come late to school are based on a lack of motivation to learn from students. This can be influenced by many things, including the lack of parental support, and the association of friends around. Schools in upholding discipline often provide sanctions as a deterrent effect, but it is not uncommon for students to keep repeating it, especially in the form of violations committed in groups.

The results of observations made by the author on February 3, 2020 found several violations in the form of the absence of students during the flag ceremony and many sitting in stalls to avoid the teacher, and absenteeism without explanation. Then, during the teaching and learning process, several students were seen chatting with their friends and going in and out of class when the teacher was explaining the lesson.

In addition, based on the results of interviews that researchers conducted with one of the school counselors and documentation studies, other forms of disciplinary violations that were categorized as severe were committed by students at Pertiwi 2 Padang Junior High School in the form of smoking at school and the participation of students in brawls. He explained that the problems that arise are caused by several factors, namely: parents who are busy working and pay less attention to their children's learning activities, parents earn a living and don't go home, parents who are imprisoned, and parents who divorce later remarry and leave their children with their grandmother. In addition, another factor that dominates the problems that arise is following the behavior of peers.

Based on the description that has been described above, it can be seen that the importance of parental support in order to increase students' learning motivation and make students excel, as well as suppress the number of peer conformity towards negative. Based on the phenomenon that the researcher has conveyed above, the researchers are interested in researching "The Contribution of Parental Support and Peer Conformity to Learning Motivation at SMP Pertiwi 2 Padang"

\section{Method}

This study uses a descriptive analytic method with a cross sectional approach, namely by collecting data at one time with the aim of finding the contribution of parental support and peer conformity to learning motivation. 
as well as describe systematically, factually, and accurately about certain facts and characteristics or try to describe phenomena in detail. The population in this study were all students of class VII and class VIII of SMP Pertiwi 2 Padang in 2020, totaling 148 students. In this study the sample was obtained using the technique of stratified random sampling namely the way of sampling for a population that has heterogeneous characteristics or the characteristics possessed by the population vary. The sample taken in this study was 108 people. The type of research instrument used in this study is a questionnaire. The scale used in this study is the Likert model scale. The research data were analyzed using descriptive techniques, then testing requirements analysis, and testing hypotheses using regression analysis techniques, then discussing the analysis.

\section{Results and Discussions}

\section{Data Description}

Based on the data obtained from the results of the administration to 108 students, all the data obtained deserves to be processed. The data of this study include the variables of parental support (X1), peer conformity (X2), and students' learning motivation (Y). The data description of each research variable is described as follows:

\section{Description of Parental Support Data}

The results of data collection and processing through parental support instruments from a total sample of 108 students can be seen in Table 8 below.

Tabel 1. Distribution of Frequency and Percentage of Parental Support $(\mathrm{X} 1)$ by Category $(\mathrm{N}=108)$

\begin{tabular}{clcc}
\hline Score Interval & \multicolumn{1}{c}{ Category } & Frequency & \% \\
\hline$\geq 185$ & Very high & 54 & 50 \\
\hline $154-185$ & Tall & 23 & 21.3 \\
\hline $123-154$ & Currently & 31 & 28.7 \\
\hline $92-123$ & Low & 0 & 0 \\
\hline 92 & Very low & 0 & 0 \\
\hline & Total & 108 & 100 \\
\hline
\end{tabular}

Based on tathe bell above, it is known from the total sample of 108 students. Overall parental support of students is in the very high category with a frequency of 54 and a percentage of $50 \%$. Furthermore, there are 23 students with high parental support with a percentage of $21.3 \%$, in the medium category as many as 31 people with a percentage of $28.7 \%$, and none in the low and very low categories. The results of the study mean that according to students their parents have given high support to learning activities.

In line with research conducted by Setiawan (2016), the results obtained where the pattern of support that occurs is relatively high, this is evident from the increasing interest in reading students and student achievement in general. There is a tendency to study hard in relation to reading interest, because in these activities the role of parents in giving attention, coaching, and material encouragement, parental social support as social factors needed by children in various aspects of development, such as learning students will carry out reading activities. . As said by Gottlieb Slameto, (2013) social support as verbal and non-verbal information, suggestions of subjects in their social environment or in the form of presence and influence on the behavior of the recipient.

\section{Peer Conformity}

The results of data collection and processing through peer conformity instruments from the entire sample (respondents) amounted to 108 students, can be seen in the following table 2 . Based on the table 2, it can be seen from the total sample of 108 students. Overall peer conformity is in the very high category with a frequency of 53 and a percentage of $49 \%$. Furthermore, there are students with high peer conformity as many as 30 people with a percentage of $28 \%$, in the medium category as many as 25 people with a percentage of $23 \%$, and none in the low and very low categories. The results of the study mean that in general, students have a strong picture of peer conformity and no low and very low peer conformity. 
Tabel 2. Description of Peer Conformity (X2) Based on Sub Variables $(\mathrm{N}=108)$

\begin{tabular}{clcc}
\hline Score Interval & \multicolumn{1}{c}{ Category } & Frequency & $\%$ \\
\hline$\geq 120$ & Very high & 53 & 49 \\
\hline $100-120$ & Tall & 30 & 28 \\
\hline $80-100$ & Currently & 25 & 23 \\
\hline $60-80$ & Low & 0 & 0 \\
\hline 60 & Very low & 0 & 0 \\
\hline & Total & 108 & 100 \\
\hline
\end{tabular}

In this diverse social environment, the condition of adolescent friendship groups has an influence on adolescent behavior (Sarwirini, 2011). In friendship, adolescents have demands for conformity. Conformity in friendship has two characteristics, namely negative conformity and positive conformity. Conformity or tendency towards positive group pressure in adolescents, for example, such as the desire to engage in activities with peers, dress like friends and the desire to take time to establish a more intense closeness with peers. Negative conformity can be in the form of using dirty language, stealing, destroying, playing truant and even making fun of parents and teachers.

\section{Motivation to learn}

The results of data collection and processing through learning motivation instruments from the entire sample (respondents) amounted to 108 students, can be seen in the following table:

Tabel 3. Distribution of Frequency and Percentage of Learning Motivation $(\mathrm{Y})$ by Category $(\mathrm{N}=108)$

\begin{tabular}{clcc}
\hline Score Interval & \multicolumn{1}{c}{ Category } & Frequency & $\%$ \\
\hline$\geq 197$ & Very high & 66 & 61 \\
\hline $164-197$ & Tall & 33 & 31 \\
\hline $132-165$ & Currently & 9 & 8.3 \\
\hline $98-132$ & Low & 0 & 0 \\
\hline 98 & Very low & 0 & 0 \\
\hline & Total & 108 & 100 \\
\hline
\end{tabular}

Based on the table above, it can be seen from the overall sample of 108 students, the overall learning motivation of students is in the very high category with a frequency of 66 and a percentage of $61 \%$. Furthermore, there are 33 students with high parental support with a percentage of $31 \%$, in the medium category as many as 9 people with a percentage of $8.3 \%$, and none in the low and very low categories. The results of the study mean that in general, students already have a picture with very high learning motivation and no low and very low learning motivation.

The condition of students' high learning motivation needs to be maintained, developed, and improved in the learning process, because after all, students arriving at this condition of learning motivation are not easy. If students have low learning motivation, it will affect student learning achievement and will affect the future of students. The results of this study are in line with the theory put forward by Sardiman (2017), namely that motivation is a condition that encourages students to carry out learning activities in order to improve the quality of learning well. If students have strong motivation, there will be a lot of energy to carry out learning activities. According to Dimyati (2016) learning motivation is relative and influenced by various factors, both from the ideals of students, the environmental conditions of students and the abilities that exist within students. These factors are very influential in increasing students' learning motivation.

\section{Research Hypothesis Testing}

First Hypothesis Testing There is a Contribution of Parental Support to Students' Learning Motivation

Tabel 4. Parental Support Regression Coefficient Test Results (X1) on Students' Learning Motivation (Y)

\begin{tabular}{ccc}
\hline Variable & $\mathbf{R}$ & R Square \\
\hline $\mathrm{X} 1-\mathrm{Y}$ & 0.627 & 0.393 \\
\hline
\end{tabular}

The table above shows that the $\mathrm{r}$ value is 0.627 , which means that there is a strong and positive relationship between parental support and learning motivation, which is 0.627 . The value of $r$ Square ( $\mathrm{r} 2$ ) is 0.393 , which means that parental support contributes to learning motivation by $39.3 \%$ while $60.7 \%$ is from other factors. 
After knowing the simple regression coefficient of parental support with learning motivation, the next step is to test the significance which aims to explain whether the variation in the value of the independent variable can explain the variation in the dependent value by using the magnitude of the $\mathrm{F}$ value.

The results of research conducted by Mayang (2018) showed that parental support and motivation to study together contributed to the relationship between students' interest in continuing their studies to college at SMA Negeri 1 Long Bagun. this means that in his research the magnitude of the relationship between parental social support and interest in continuing college education in adolescents.

Students with low motivation will experience problems in learning, for example, do not care about everything related to school activities, are slow to do tasks related to learning activities, easily give up, neglect schoolwork, become lazy, and like to play truant. This will have a negative impact on the success of learning. According to Syah (2012) that lack or lack of motivation, both internal and external, will cause students to be less enthusiastic in carrying out the learning process of subject matter both at school and at home.

\section{Second Hypothesis Test There is Peer Conformity to Participants' Learning Motivation}

Tabel 5. Simple Regression Coefficient Peer Conformity Test Results (X2) on Students' Learning Motivation (Y)

\begin{tabular}{ccc}
\hline Variable & $\mathbf{R}$ & R Square \\
\hline $\mathrm{X} 2-\mathrm{Y}$ & 0.723 & 0.522 \\
\hline
\end{tabular}

Based on the table above, it can be seen that the $r$ value is 0.723 , which means that there is a strong relationship between peer conformity and students' learning motivation. The value of $r$ Square (r2) is 0.522 , which means that peer conformity contributes to the learning motivation of students by $52.2 \%$ while $47.8 \%$ is a contribution from other factors. After knowing the simple regression coefficient of peer conformity with learning motivation, the next step is a significance test that aims to explain whether the variation in the value of the independent variable can explain the variation in the dependent value by using the magnitude of the $\mathrm{F}$ value.

Having friends who encourage you to try harder at school can provide encouragement or motivation if your child isn't doing their best. Friends are also able to prevent neglect of obligations and help in times of trouble. They can motivate each other and point in the right or positive direction. Many children are able to break free from self-destructive habits under the influence of caring peers. These are examples of positive peer pressure (Herron and Peter: 2015).

\section{Third Hypothesis Test There is Parental Support and Peer Conformity on Learning Motivation}

Tabel 6. The results of the Multiple Regression Coefficient of Parental Support Variables (X1) and Peer Conformity (X2) on Students' Learning Motivation (Y)

\begin{tabular}{ccc}
\hline Variable & $\mathbf{R}$ & R Square \\
\hline X1 X2Y & 0.736 & 0.542 \\
\hline
\end{tabular}

The table above shows that the $\mathrm{R}$ value is 0.736 , which means that there is a strong relationship between parental support and peer conformity with learning motivation, which is 0.736 . The value of $R$ Square (R2) is 0.542 , which means that parental support and peer conformity together on learning motivation is $54.2 \%$ while $45.8 \%$ is influenced by other factors. After knowing that the multiple correlation coefficients of parental support and peer conformity are associated with learning motivation, the next step is to carry out a significance test which aims to explain whether the variation in the value of the independent variable can explain the variation in the dependent value by using the magnitude of the $F$ value.

Based on the series of analyzes described above, it can be understood that there are a number of main keys in increasing students' learning motivation, the main influence being increasing students' learning motivation, the main influence being parental support. This is because parents are part of the family, namely as adults who are closest to children. Parents are someone who will be a protector, support, and ready to help alleviate any problems their children have. Such parents are parents who always support their children. According to Sarafino (2012) parental support is very influential on the success of their children in learning. Thus, parental support is one of the factors that contribute to students' learning motivation. 
Meanwhile, peers (peer groups) who have a negative influence, students lack the motivation to learn, because they are more likely to do things that are fun. Groups or peers who have a positive influence will be able to increase high learning motivation for the education of students, the emergence of a sense of solidarity, being able to work together with others and so on. While the association of peer groups that have a negative influence will make students ignore their education, tend to lead to deviant behavior, the emergence of juvenile delinquency and other destructive behavior (Nasution \& Islam, 2018).

\section{Conclusions}

Based on the findings and discussion of the research results, the following conclusions can be drawn. On average, the picture of parental support for students at SMP Pertiwi 2 Padang is in the very high category. This shows that in general the subjects in this study have high parental social support for their children. Then, the picture of peer conformity at SMP Pertiwi 2 Padang is in the very high category. This shows that in general the subjects in this study have a positive contribution between peers on learning motivation. Next, the description of the learning motivation of the students of SMP Pertiwi 2 Padang is in the very high category. This states that students already have high learning motivation. Then, parents contribute to the learning motivation of the students of SMP Pertiwi 2 Padang. That is, the higher the contribution of parents, the higher the learning motivation of students, or vice versa if the contribution of parents is low, it will result in the learning motivation of students getting lower. Peers contribute to the learning motivation of the students of SMP Pertiwi 2 Padang. That is, positive peer pressure can bring the behavior of students to be positive as well, including in increasing learning motivation. Parental support and peer conformity contribute jointly to the learning motivation of the students of SMP Pertiwi 2 Padang. That is, parental support and peer conformity together can be a factor that influences students' learning motivation

\section{References}

Dimyati, M. (2016). Model-model pengajaran dan pembelajaran. Teaching and Educations.

Gonzalez-DeHass, A. R., Willems, P. P., \& ... (2005). Examining the relationship between parental involvement and student motivation. Educational psychology Voleme 17(2).

Herdiyanto, Y. K., \& Yuliantari, I. M. (2015). Hubungan Konformitas Dan Harga Diri Dengan Perilaku Konsumtif Pada Remaja Putri Di Kota Denpasar. Jurnal Psikologi Udayana, 2.

Iskandar, M. P. (2009). Psikologi Pendidikan Sebuah Orientasi Baru. Ciputat: Gaung Persada (GP) Press.

Laila, Y., \& Ilyas, A. (2019). Hubungan Konformitas Teman Sebaya dengan Motivasi Belajar di SMA Adabiah Padang, 1.

Malwa, R. U. (2018). Dukungan Sosial Orangtua Dengan Motivasi Belajar Siswa Putra Tahfidz Al-Qur'an. Psikis: Jurnal Psikologi Islami, 3.

Mayang, Y. (2018). Hubungan Dukungan Orangtua dan Motivasi dengan Minat Melanjutkan Studi ke Perguruan Tinggi. Psikonborneo, 6.

Prawira, P. A., \& Atmaja, P. (2012). Psikologi pendidikan dalam perspektif baru. difarepositories.uin-suka.ac.id

Sarafino, E. P., Timothy W. Smith. 2012. Health Psychology: Biopsychosocial Interactions, 7th edition. Amerika Serikat: John Wiley \& Sons, Inc.Sardiman, A. M. (2017a). Interaksi dan Motivasi Belajar Mengajar: Bandung. Rajawali Pers.

Sarwirini. (2011). Kenakalan Anak (Juvenile Delinquency) Kausalitas dan Upaya Penanggulangannya. Perspektif, XVI.

Setiawan. (2016). Dukungan sosial orangtua dalam menumbuhkan minat baca pada siswa kelas VII di SMP Negeri 3 Sewon Bantul. Spektrum Analisis Kebijakan Pendidikan, 4.

Setiyo, B. (2017). Konformitas teman sebaya dan kedisiplinan terhadap motivasi belajar pada siswa sekolah menengah atas. Jurnal Psikologi, 2.

Slameto. (2013). Belajar dan faktor-faktor yang mempengaruhinya. Jakarta: Rineka Cipta.

Syah (2012). Psikologi perkembangan anak dan remaja. Bandung: Remaja Rosdakarya, Volume 1 No 4.

Uno, H. B., \& Mohamad, N. (2011). Belajar dengan pendekatan PAILKEM. Jakarta: Bumi Aksara.

Yulia. (2019). Hubungan Antara Dukungan Orangtua Dengan Motivasi Belajar Pada Remaja. Psikoborneo, 7. 